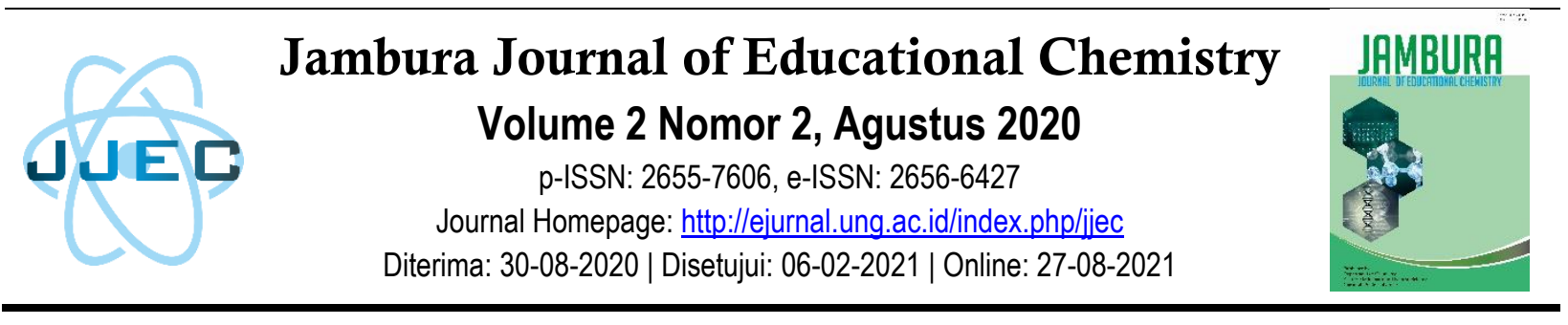

\title{
Pengaruh Model Pembelajaran IKRAR Terhadap Hasil Belajar Siswa Kelas XI IPA SMA Negeri 4 Gorontalo pada Materi Larutan Penyangga
}

\author{
Risma Malakah¹, Mardjan Paputungan², Opir Rumape ${ }^{3}$ \\ 1,2,3 Prodi Pendidikan Kimia, Jurusan Kimia, Fakultas MIPA, Universitas Negeri Gorontalo \\ 3 Prodi Kimia, Jurusan Kimia, Fakultas MIPA, Universitas Negeri Gorontalo \\ Jl. Prof. Dr. Ing. B. J. Habibie, Moutong, Tilongkabila, Kabupaten Bone Bolango, Gorontalo \\ 96119, Indonesia \\ e-mail: ${ }^{1}$ risma24malaka@gmail.com
}

\begin{abstract}
Abstrak
Penelitian ini bertujuan untuk mengetahui pengaruh model pembelajaran IKRAR terhadap hasil belajar siswa kelas XI IPA SMA Negeri 4 Gorontalo pada materi larutan penyangga. Desain penelitian yang digunakan adalah Quasi Eksperimental dengan rancangan Pretest Posttest Control Group Desain. Sampel penelitian berjumlah 30 siswa yaitu sebanyak 15 siswa pada kelas eksperimen dan 15 siswa pada kelas kontrol. Kelas eksperimen menggunakan model Pembelajaran IKRAR (Inisiasi, konstruksi-rekonstruksi, aplikasi, dan refleksi) sedangkan kelas kontrol menggunakan model Konvensional. Adapun instrument yang digunakan dalam penelitian ini yaitu instrument dengan bentuk tes tulis yang digunakan adalah tipe esai yang berjumlah 10 soal. Analisis data untuk pengujian hipotesis menggunakan uji-t. Hasil dari analisis data tersebut diperoleh $t_{\text {hitung }}>$ $\mathrm{t}_{\text {tabel }}$ pada taraf signifikan 0.10 dengan $\mathrm{dk}=28$, maka $\mathrm{H}_{0}$ ditolak dan $\mathrm{H}_{1}$ diterima. Hal ini menunjukkan bahwa terdapat pengaruh model pembelajaran IKRAR terhadap hasil belajar siswa pada materi larutan penyangga.
\end{abstract}

Kata kunci: Model Pembelajaran IKRAR, Hasil Belajar Siswa, Larutan Penyangga

\section{PENDAHULUAN}

Pembelajaran merupakan proses interaksi peserta didik dengan pendidik dan sumber belajar pada suatu lingkungan belajar (Undang-Undang Republik Indonesia, 2003). Untuk menghasilkan proses pembelajaran yang baik maka proses interaksi yang terjadi antara peserta didik dengan pendidik dan peserta didik dengan sumber belajar lainnya harus berjalan dengan kondusif. Ketika kondisi pembelajaran sudah dalam keadaan kondusif maka proses pembelajaran akan berjalan baik dan secara langsung akan berakibat terhadap peningkatan hasil belajar siswa (Arikunto \& Suhardjono, 2006).
Proses belajar mengajar adalah proses menciptakan suasana dan lingkungan belajar untuk menghasilkan perubahan struktur kognitif pada siswa. Perubahan struktur kognitif tersebut ditandai dengan adanya peningkatan hasil belajar yang dialami oleh siswa. Oleh karena itu, proses pembelajaran sangat erat kaitannya dengan hasil belajar yang diperoleh siswa (Hamdani, 2011).

Selama proses pembelajaran, siswa dituntut untuk mengenali kemampuan dirinya, baik itu kelebihan maupun kekurangannya (self-reflection) (Hamdani, 2011). Siswa harus bisa mengidentifikasi apa yang mereka harus lakukan dalam menyelesaikan persoalan ketika belajar, 
sehingga ketika hal tersebut bisa terjadi maka kesadaran siswa untuk memahami pembelajaran akan semakin meningkat. Meningkatkan kesadaran siswa dalam belajar sangat penting untuk membangun kesadaran berpikir mengenai apa yang dia ketahui dan tidak diketahuinya. Dalam konteks pembelajaran, ketika siswa sudah memiliki kesadaran tersebut maka siswa akan mengetahui bagaimana ia seharusnya belajar, mengetahui kemampuan dan modalitas yang dimiliki, serta mengetahui strategi belajar yang paling baik agar lebih efektif (Lidinillah, 2008).

Salah satu faktor yang menyebabkan kurangnya kemampuan siswa dalam memecahkan masalah yakni faktor kebiasaan belajar siswa. Biasanya siswa hanya belajar dengan cara menghafal, metode ini dinilai tidak dapat melatih kemampuan pemecahan masalah pada siswa tersebut (Djamarah, 2002). Faktor selanjutnya adalah selama proses belajar siswa hanya melakukan pembelajaran secara berkelompok tanpa dipandu oleh guru dan menerima apa saja yang diberikan oleh guru selama proses pembelajaran di dalam kelas (Hanifah, Azmi, \& Haryati, 2019).

Model pembelajaran IKRAR (Inisiasi, Kontruksi-Rekontruksi, Aplikasi dan Refleksi) adalah salah satu model pembelajaran yang melibatkan kemampuan pemecahan masalah dalam proses pembelajaran (Hidayah, Syahmani, \& Iriani, 2014). Model pembelajaran IKRAR adalah model pembelajaran yang sesuai dengan paham konstruktivis yakni dalam proses pembelajaran siswa dituntut harus aktif dalam mengkonstruksi konsep saat diberikan suatu masalah diberikan (Putri, Dhewy, \& Kusumawati, 2019). Model IKRAR adalah salah satu model pembelajaran inovatif yang dikembangkan pertama kali oleh Sudiarta pada tahun 2007, dihasilkan dari berbagai penelitian tentang pemecahan masalah yang telah disesuaikan dengan kondisi peserta didik dalam konteks Indonesia. Pada model pembelajaran IKRAR didasari oleh paradigma konstruktivistik, dimana siswa tidak menerima informasi secara pasif, tetapi siswa aktif mengkonstruksi pengetahuannya. Pembelajaran dengan menggunakan model IKRAR menempatkan siswa sebagai pelaku utama dalam pembelajaran, sehingga memungkinkan siswa untuk dapat memahami sendiri suatu konsep dan meningkatkan kemampuan pemecahan masalah (Hidayah et al., 2014).

Pembelajaran kimia merupakan pembelajaran yang menekankan pada pemberian pengalaman belajar secara langsung dengan melalui penggunaan dan pengembangan keterampilan proses serta sikap ilmiah (Desni, Sihaloho, \& Pikoli, 2019). Dengan model pembelajaran yang tepat hal ini dapat merangsang siswa untuk menganalisis dan menyelesaikan persoalan kimia yang ditemui.

Berdasarkan latar belakang masalah yang telah diuraikan, maka peneliti mengidentifikasi masalah yaitu: Proses belajar mengajar masih terpusat pada guru, kurangnya aktivitas siswa dalam pembelajaran, cara belajar siswa yang masih kurang tepat, kurangnya kemampuan siswa dalam pemecahan masalah. Adanya masalah-masalah tersebut dapat menyebabkan rendahnya hasil belajar siswa. Rumusan masalah dalam penelitian ini adalah apakah terdapat pengaruh model pembelajaran IKRAR terhadap hasil belajar siswa pada materi larutan penyangga?

Berdasarkan rumusan masalah, maka tujuan penelitian ini adalah untuk melihat seberapa besar pengaruh model pembelajaran IKRAR terhadap hasil belajar siswa kelas XI IPA SMA Negeri 4 Gorontalo pada materi larutan penyangga.

\section{METODE PENELITIAN}

Metode dalam penelitian ini adalah quasi eksperimental (ekperimen semu) dengan PretestPosttest Control Group Design.

\section{Jenis Penelitian}

Penelitian ini menggunakan pendekatan kuantitatif.

\section{Waktu dan Tempat Penelitian}

Penelitian ini dilaksanakan di SMA Negeri 4 Gorontalo yang bertempat Jl. Brigjen Piola Isa, Wongkaditi, Kota Utara, Kota Gorontalo, Provinsi Gorontalo. Penelitian ini dilaksanakan pada semester genap tahun ajaran 2019/2020.

\section{Target/Subjek Penelitian}

Subjek dari penelitian ini adalah siswa kelas XI IPA SMA Negeri 4 Gorontalo tahun pelajaran 2019/2020 sebanyak 30 siswa. 


\section{Prosedur}

Penelitian ini menggunakan dua kelas yaitu kelas XI IPA 1 dan kelas XI IPA 2 yang diambil dengan cara menggunakan random sampling untuk penerapan perlakukan penelitian. Kelas XI IPA 1 digunakan untuk perlakuan dengan menggunakan model IKRAR (kelas ekperimen), sedangkan kelas XI IPA 2 digunakan untuk dengan menggunakan model pembelajaran Konvensional (kelas kontrol).

\section{Teknik Pengumpulan Data}

Pengumpulan data dalam penelitian ini diperoleh dari tes keterampilan dalam memecahkan suatu masalah sebagai instrumen penelitian yang diberikan sebelum dan setelah diterapkan model pembelajaran IKRAR pada kelas eksperimen dan model pembelajaran konvensional pada kelas kontrol. Jenis tes yang digunakan berupa tes uraian sebanyak 10 butir soal esai.

\section{Teknik Analisis Data}

Tehnik analisis data yang digunakan yaitu 1) Uji N-Gain digunakan untuk memberikan gambaran umum peningkatan skor hasil pembelajaran sebelum dan sesudah diterapkannya model pembelajaran IKRAR 2) Uji normalitas data diperlukan untuk mengetahui bahwa data yang diambil berasal dari populasi yang berdistribusi normal atau tidak. Secara statistik dapat digunakan dengan metode liliefors untuk menguji hipotesis, 3) Uji homogenitas dilakukan untuk meyakinkan bahwa sampel memiliki varians yang homogenitas di berlakukan uji barllet, 3) Uji-t untuk melihat pengaruh model pembelajaran IKRAR terhadap hasil belajar siswa.

\section{HASIL DAN PEMBAHASAN}

Hasil dari penelitian ini berupa skor pretesst dan postesst untuk model pembelajaran IKRAR dan model pembelajaran Konvensional. Dengan jumlah sampel 30 siswa yang terdiri dari kelas eksperimen berjumlah 15 siswa dan kelas kontrol berjumlah 15 siswa. Adapun data yang digunakan dalam penelitian ini yaitu menggunakan tes dalam bentuk esai, kemudian di olah secara kuantitatif dengan menggunakan uji statistik yang di tentukan. Pengambilan data dilakukan sebanyak dua kali berupa pretest dan posttest, yaitu pada kelas yang dilakukan penelitian.

\section{Uji Normalitas}

Digunakan untuk menguji data berdistribusi normal atau tidak. Uji normalitas dalam penelitian ini menggunakan uji liliefors. Kriteria pengujiannya adalah $\mathrm{H}_{0}$ diterima jika $\mathrm{L}_{\text {hitung }}$ $\leq \mathrm{L}_{\text {tabel }}$ dan tolak $\mathrm{H}_{0}$ jika $\mathrm{L}_{\text {hitung }} \geq \mathrm{L}_{\text {tabel }}$ pada taraf signifikan $\alpha=0.05$ (5\%). Hasil uji normalitas dapat dilihat pada Tabel 1.

Tabel 1. Uji Normalitas menggunakan uji Liliefors

\begin{tabular}{|c|c|c|c|c|c|}
\hline $\begin{array}{l}\mathbf{N} \\
\mathbf{0}\end{array}$ & Data & Kelas & Lhitung & Ltabel & $\begin{array}{c}\text { Kesimp } \\
\text { ulan }\end{array}$ \\
\hline \multirow{2}{*}{1} & Pre- & $\mathrm{A}$ & 0,210 & 0,220 & \multirow{2}{*}{ Normal } \\
\hline & Test & B & 0,219 & 0,220 & \\
\hline \multirow{2}{*}{2} & Post- & $\mathrm{A}$ & 0,143 & 0,220 & \multirow{2}{*}{ Normal } \\
\hline & Test & B & 0,181 & 0,220 & \\
\hline
\end{tabular}

Keterangan:

$\mathrm{A}=$ Kelas Eksperimen

$\mathrm{B}=$ Kelas Kontrol

\section{Uji Homogenitas}

Digunakan dengan tujuan untuk mengetahui apakah nilai yang dimbil untuk kelas eksperimen dan kelas kontrol mempunyai varians yang homogen. Pada penelitian ini digunakan uji Barllett. Hasil uji homogenitas tes hasil belajar siswa dapat dilihat pada Tabel 2.

Tabel 2. Uji Homogenitas menggunakan uji Bartllett

\begin{tabular}{cccc}
\hline Data & $\mathbf{X}_{\text {hitung }}$ & $\mathbf{X}_{\text {tabel }}$ & Kesimpulan \\
\hline Pretest A dan B & 8,85 & 11,07 & Homogen \\
\hline Posttest A dan B & 0,042 & 22,36 & Homogen \\
\hline
\end{tabular}

Keterangan :

$\mathrm{A}=$ Eksperimen

$\mathrm{B}=$ Kontrol

Berdasarkan tabel hasil uji homogenitas diatas diperoleh bahwa $\mathrm{X}_{\text {hitung }} \leq \mathrm{X}_{\text {tabel }}$ sehingga $\mathrm{H}_{0}$ diterima.

\section{Pengujian Hipotesis}

Setelah uji normalitas dan homogenitas terpenuhi dan data telah berdistribusi normal serta berasal dari populasi yang homogen, selanjutnya dilakukan pengujian hipotesis untuk melihat pengaruh model pembelajaran IKRAR terhadap hasil belajar siswa dengan menggunakan uji t. dengan kriteria pengujian: Terima $\mathrm{H}_{0}$ jika $\mathrm{t}$ hitung $\leq$ $\mathrm{t}$ tabel dan terima $\mathrm{H}_{1}$ jika $\mathrm{t}$ hitung $\geq \mathrm{t}$ tabel 
$\mathrm{H}_{0}=$ Tidak terdapat pengaruh model pembelajaran IKRAR terhadap hasil belajar siswa pada materi larutan penyangga

$\mathrm{H}_{1}=$ Terdapat pengaruh model pembelajaran IKRAR terhadap hasil belajar siswa pada materi larutan penyangga

Data Uji-t dapat dilihat pada Tabel 3.

Tabel 3. Pengujian Hipotesis menggunakan Uji-t

\begin{tabular}{ccrrrc}
\hline Kelas & Rata-rata & DK & $\mathbf{T}_{\text {hiting }}$ & $\mathbf{T}_{\text {tabel }}$ & Ket \\
\hline $\mathrm{A}$ & 67,66 & 28 & 1,55 & 1,31 & $\mathrm{H}_{1}$ Diterima \\
\hline $\mathrm{B}$ & 65,26 & & & & \\
\hline
\end{tabular}

Keterangan:

$\mathrm{A}=$ Eksperimen

$\mathrm{B}=$ Kontrol

Dari perhitungan tersebut didapatkan hasil t hitung $=1,55$ sedangkan $\mathrm{t}$ tabel $=1,31$. Dengan demikian diketahui bahwa $\mathrm{t}$ hitung $\geq \mathrm{t}$ tabel yaitu $1,55 \geq 1,31$ yang berarti $\mathrm{H}_{1}$ diterima dan $\mathrm{H}_{0}$ ditolak. Hal ini menunjukan bahwa terdapat pengaruh model pembelajaran IKRAR terhadap hasil belajar siswa.

\section{Uji $N$-Gain}

Digunakan untuk memberikan gambaran umum peningkatan skor hasil pembelajaran sebelum dan sesudah diterapkannya model pembelajaran IKRAR. Kriteria pengelompokan $N$ Gain dapat dilihat pada Tabel 4. Hasil uji N-Gain dari kelas ekperimen dan kelas kontrol dapat dilihat pada Tabel 5.

Tabel 4. Kriteria Pengelompokan N-Gain

\begin{tabular}{cc}
\hline $\boldsymbol{N}$-Gain & Kriteria \\
\hline $\mathrm{G} \geq 0,7$ & Tinggi \\
\hline $0,3 \leq \mathrm{G} \leq 0,7$ & Sedang \\
\hline $\mathrm{G} \leq 0,3$ & Rendah \\
\hline
\end{tabular}

Tabel 5. Hasil Uji N-Gain

\begin{tabular}{ccc}
\hline & Kelas Eksperimen & Kelas Kontrol \\
\hline Pretest & 34,06 & 39,66 \\
\hline Posttest & 67,66 & 65,26 \\
\hline N-Gain & 0,53 & 0,45 \\
\hline Keterangan & Sedang & Sedang \\
\hline
\end{tabular}

Berdasarkan data tersebut, hasil perhitungan $\mathrm{N}$-gain kelas diperoleh rata-rata pretest sebesar 34,06 dan rata-rata posttest sebesar 67,66. Sehingga diperoleh $N$-gain 0,53. Artinya kelas eksperimen mengalami peningkatan hasil belajar sebesar 53\% dengan kategori sedang karena 0,7 > g $\geq 0,3$. Pada kelas kontrol diperoleh rata-rata pretest 39,66 dan rata-rata posttest 65,26. Sehingga diperoleh $N$-gain 0,45 . Artinya kelas Kontrol juga mengalami peningkatan hasil belajar $45 \%$, dalam kategori sedang karena $0,7>\mathrm{g} \geq 0,3$.

\section{KESIMPULAN}

Berdasarkan data-data penelitian dan hasil perhitungan diperoleh bahwa model pembelajaran IKRAR berpengaruh positif terhadap hasil belajar siswa, dimana untuk uji $\mathrm{t}$ hasil yang diperoleh $\mathrm{t}$ ttabel $<$ thitung atau $1.31253<1,550$. Hasil tersebut menunjukkan bahwa terdapat pengaruh model pembelajaran IKRAR terhadap hasil belajar siswa pada materi larutan penyangga.

\section{UCAPAN TERIMA KASIH}

Terima kasih saya sampaikan kepada Bapak Drs. Mardjan Paputungan, M.Si selaku Penasehat Akademik serta Pembimbing I dan Bapak Dr. Opir Rumape, M.Si selaku Pembimbing II yang telah meluangkan waktu membimbing dan membantu serta memberikan arahan kepada penulis hingga menyelesaikan artikel ini.

\section{DAFTAR PUSTAKA}

Arikunto, S., \& Suhardjono, S. (2006). Penelitian tindakan kelas. Jakarta: Bumi Aksara.

Desni, N. W., Sihaloho, M., \& Pikoli, M. (2019). Studi Komparasi Kemampuan Berpikir Kritis Siswa Menggunakan Model Pembelajaran Problem Based Learning dan Discovery Learning Pada Materi Larutan Penyangga di Kelas XI SMA Negeri 1 Telaga. Jambura Journal of Educational Chemistry, 1(2), 6368.

Djamarah, S. B. (2002). Psikologi belajar. Jakarta: PT. Rineke Cipta.

Hamdani. (2011). Strategi Belajar Mengajar. Bandung: Pustaka Setia.

Hanifah, N., Azmi, J., \& Haryati, S. (2019). Penerapan Model Pembelajaran IKRAR (Inisiasi, Konstruksi-Rekonstruksi, Aplikasi, Refleksi) untuk Meningkatkan Hasil Belajar Peserta Didik pada Pokok Bahasan Kesetimbangan Kimia di Kelas XI MIA SMA Negeri 9 Pekanbaru. Jurnal Online 
Mahasiswa, 6(1), 1-9.

Hidayah, N., Syahmani, S., \& Iriani, R. (2014). Penerapan Strategi Metakognitif dengan Model Pembelajaran Ikrar untuk Meningkatkan Hasil Belajar pada Materi Larutan Penyangga dan Hidrolisis Garam Siswa Kelas XI-IPA SMA Darul Hijrah Putri Martapura. Quantum: Jurnal Inovasi Pendidikan Sains, 5(2).

Lidinillah, D. A. M. (2008). Strategi pembelajaran pemecahan masalah di Sekolah Dasar. Jurnal Pendidikan Dasar, 10, 1-5.
Putri, R. M., Dhewy, R. C., \& Kusumawati, I. B. (2019). Pengaruh Model Pembelajaran Inisiasi, Konstruksi- Rekonstruksi, Aplikasi, Refleksi (IKRAR) terhadap Hasil Belajar Siswa (STKIP PGRI Sidoarjo). STKIP PGRI Sidoarjo. Retrieved from https://repository.stkippgrisidoarjo.ac.id/661/

Undang-Undang Republik Indonesia. Sistem Pendidikan Nasional. , Pub. L. No. Nomor 20 Tahun 2003 (2003). 